\title{
Education to Educate: A Case of Punjab Education Foundation
}

\author{
Sayeda Zeenat Maryam, Umm-e-Amen, Adeena Safdar, Anam Shehzadi, \\ Sayyed Khawar Abbas
}

Hailey College of Commerce, University of the Punjab, Lahore, Pakistan

\begin{abstract}
Mrs. Shehzad's doorbell rang, and she came out to open the door. She was sure about the arrival of her children Ali and Sana on the door as it was the time of school closing at 3'o clock. While serving the lunch, she thanked Allah and recalled the time a few years back. When Ali was in $4^{\text {th }}$ grade, and Sana was in $5^{\text {th }}$ grade, $M r$. \& Mrs. Shahzad thought to change the school of their children from private to government. This thought emerged because they were unable to afford the fee schedule of private schools. But they were aware of the drawbacks of Government Schools too. They never wanted to abolish their children's confidence level, productivity, and learning. It was not the dilemma of one home but the whole nation.
\end{abstract}

Keywords - Punjab Education Foundation, Education, Government schools.

\section{INTRODUCTION}

Education is considered as the most important key driver to run an economy, and it encircles all aspects of life. We can't even imagine anything without this factor. Education is the necessity of life and key success factor of any nation. The education system of Pakistan is not much credible and strong as well as stable, so it categorizes Pakistan as developing country. Due to this big reason along with few constraints, Pakistan after 68 years of independence still considered as developing Nation. The education system overlooked throughout the decades.

\section{History of Education in Pakistan}

Under Article 25-A of Constitution of Pakistan, the ruling government will be liable to provide free quality education to students who are between the age group of 5 to 16 years. If we look towards traditional education system which is portrayed by Pakistan developed through Islamic Arabic culture which comes to us from the Indian subcontinent. We can figure out the effects of Muhammad Bin Qasim's Invasion in Sindh in 712 AD as well as Sir Syed Ahmed Khan's (1817-1898) tireless work of education of Muslims, on the traditional education system. Even after Independence, Quaid e Azam followed the crafted reforms and strategies of Sir Syed. After independence, Muhammad Ali Jinnah invited many teachers, Professors and consultants to Pakistan which came from India and England. Through combinedefforts, they designed the Curriculum and Teaching Strategies. With the passage of time, the quality of education disappeared. Although, many educational systems and reforms adopted which included the National and British educational Systems. ${ }^{[1]}$

Issue between private and Publics sector schooling During 1970's after the nationalization of all private schools, severe restriction was made at growth of that sector and potential, fast forward twenty years and you will see private sector schools have re-emerged again. After that, private schools were more in demand than before due to massive problems in public school system. Nationally in Pakistan overall private school enrollment was $13 \%$ at that time but in 2002 it became $60 \%$. $^{[4]}$

According to the Human Development in South Asia's 1998 report following were lacking points of Public schools.

\begin{tabular}{ccc}
\hline $\begin{array}{c}\text { Sr. } \\
\text { no. }\end{array}$ & Public school \% & Lacking Necessity \\
\hline 1 & $70 \%$ & Toilet \\
2 & $68 \%$ & Water \\
3 & $92 \%$ & Play Grounds \\
4 & $60 \%$ & Boundary walls \\
5 & $16 \%$ & Building \\
\hline
\end{tabular}

Furthermore, a delegation of UK, while reporting the situation of Public schools in Pakistan described the lacking points such as shortage of furniture, electricity, windows, blackboards, etc. As well as, there were overcrowded classrooms and "ghost schools," schools getting government grants but doesn't exist. ${ }^{[4]}$

The need of Punjab Education Foundation

In prescribed context govt. Schools due to massive problems were not able to provide quality education whereas private schools feed expensively. So there was a need for an organization which might be able to serve the Nation with a quality education without any concept of monetary profit for the sake of the public. Punjab Education Foundation established in 1991. 


\section{Brief History of Punjab Education Foundation}

The Punjab Education Foundation initiated under the Punjab Education Foundation act presented in 1991, as an autonomous statutory body to encourage education on no profit basis. Since going through the prescribed pattern, it seems difficult to arrange free and quality education for deserving students at their ease. PEF has been restructured under the Punjab Education Foundation ActXII of 2004 for enhancement of education while encouraging the efforts of Private sector providing education to poor through Public-private Partnership. ${ }^{[2]}$ Punjab Education Foundation is promoting free quality education in Punjab under the umbrella of public-private partnership; its long-run objective is to promote educated society so that every child should have access to the basic right of education in Punjab. [3]

The Board formulated as strategy flexible approach. The salient features are:

- Provision of the low-income households for better quality education by the private sector

- The technical assistance of privately managed schools

- Support of the schools of less affluent areas

- Promote female education

- Financial assistance through new instruments on the basis of per child enrollment

- Vouchers for the slums/kachiabadis households.

- The monetary reward for well-reputed institutions

\section{The tradeoff between private and public sector}

PEF is performing a pivotal role in trading off between private and public sector, helping to resolve the problems of both sectors and fulfilling the need of being educated to several sectors of societies. PEF having 15 boards of directors has a chairman who is selective head by private members. Foundation is innovatively intervening education to disenfranchised and less-privileged sections of society, through Public Private Partnership. It introduced economic, affordable and cost-effective models to educate the deserving ones.

These have gained international and national appreciation. PEF utilizes four Strategies to bridge the gap between these sectors.

\section{FOUNDATION ASSISTED SCHOOLS (FAS)}

PEF initiated Foundation Assisted Schools (FAS), through PPP; it assisted the poor strata of society under the flagship of PEF in Punjab. Foundation Assisted schools were having background in 2005 when it was initiated with outreach in 6 districts, till now it is extended in36 districts in Punjab. The number of schools having Partnership with PEF under FAS reached around 3000 and their induction came through nine phases to cater the need of 1.3 million students. FAS targeted rural, Slum and Urban areas in Punjab to promote and encourage quality education while giving financial as well as technical support to its partners. Under FAS, PEF faced the problem to spread the flagship because here private sector was very efficiently earning heavy profits. PEF captured their intention to educate and while focusing that intention they tried to compile their intention of profit as well as, for that cause PEF offered them level wise fee to compensate them for the sake of their opportunity cost of profit in a way. PEF gave their partner schools per month fee Rs. 450 up to Primary Classes, Rs. 500 up to Elementary Classes, 600 up to secondary arts classes, Rs. 700 up to secondary level science students, Rs. 800 up to higher secondary Arts students and Rs. 1000 up to higher secondary science students, per head. This planning of FAS proved very successful. FAS are also running an android app which asks to help PEF to send children to school to promote their cause and objective. Moreover their Newsletters and E-Newsletters are also spreading their motives very efficiently. PEF publish their annual report every year and sent it to almost all stakeholders along with detail of expenditure on different programs for their information purpose. Audit report transparency also added value to trust of PEF for their stakeholders. PEF achieved more transparency and prudence every year along with three different audits, those includes governmental, external and internal audits, and these make PEF more credible. Through this credibility and trust PEF targeted the children at their best extent, renovating them with education. We can see the bar chart given below, these are the districts where $70.76 \%$ schools of FAS are geographically located and number of schools is mentioned. We can see most schools are in the district Muzaffargarh which are 293 and in Bahawalpur 284 schools are under FAS. Whereas Multan, Bahawalnagar, Lodhran, Jhang, Rajanpur, Vehari and D.G. Kahn are further districts with high number of schools. These districts are more targeted till now. Total students till yet benefited though FAS are 1,326,047 which is really impressive statistic. We can see the breakup of these students in boys and girls in the pie chart below and could figure out the proportionate too. 


\section{Foundation Assissted Schools (FAS)}

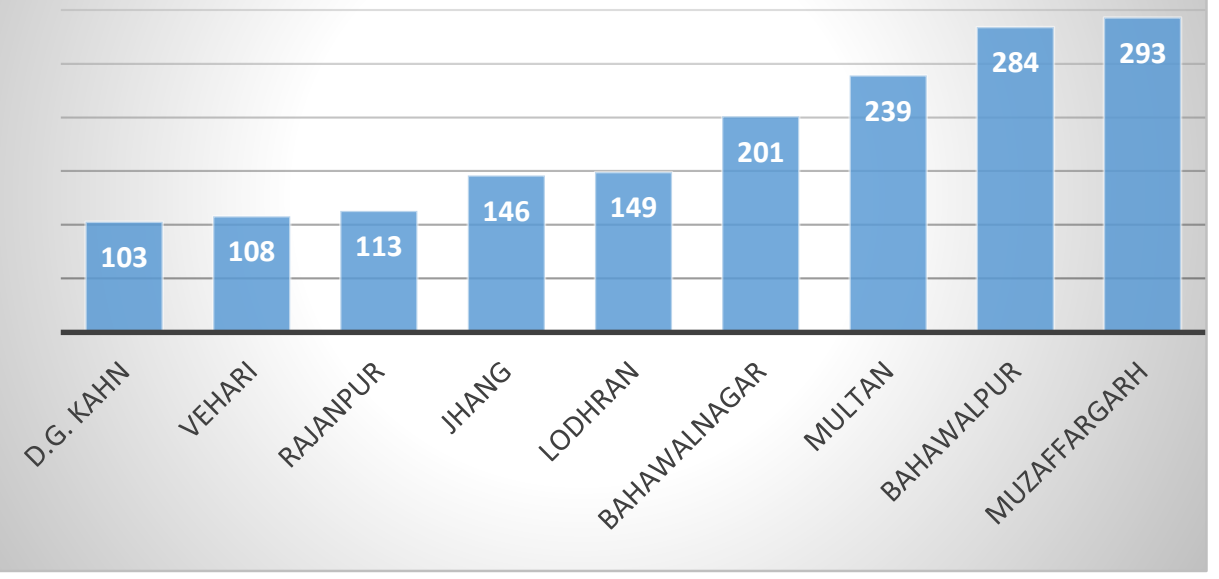

\section{STUDENTS BENEFITED UNDER FAS}

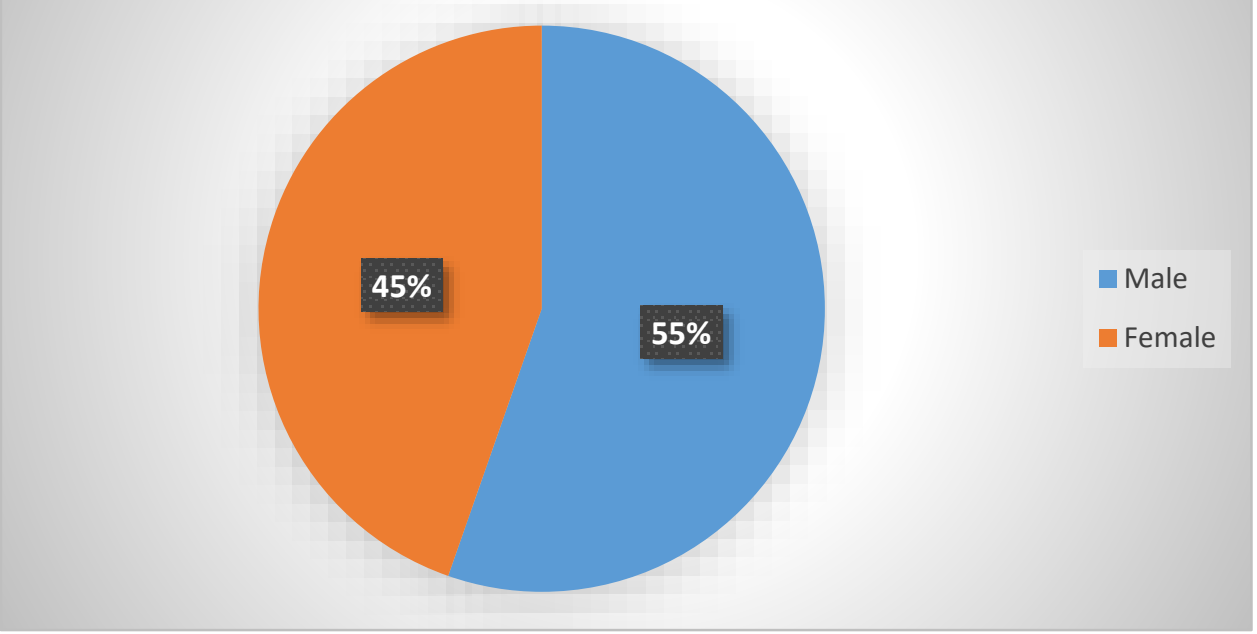

PEF-FAS, first of all, select their partners with very effective criteria, new phase launched in national dailies and schools apply for the partnership with the PEF. Later, school passes the Quality Assurance Test by PEF upon prescribed criteria in the advertisement. Qualified school gets through physical inspection for infrastructure and is then selected and offereda partnership with PEF. After determining the authenticity of documents of school, the school gets ascertained before school becomes the partner of FAS.

\section{CONTINUOUS PROFESSIONAL DEVELOPMENT PROGRAM (CPDP)}

The second strategy utilized by PEF was CPDP, launched in 2005, its core function was to technically train and assist PEF partner school teachers and Heads during service. All these training were meant to enhance and ensure quality education. They use the following team.

\begin{tabular}{lll}
\hline $\begin{array}{l}\text { Sr. } \\
\text { No. }\end{array}$ & $\begin{array}{l}\text { Number of } \\
\text { members }\end{array}$ & Group \\
\hline 1 & 14 & $\begin{array}{l}\text { Personnel to manage } \\
\text { administrative side } \\
\text { MFTs ( Monitor/ Facilitator/ } \\
\text { Trainer) } \\
2\end{array}$ \\
& 41 & Subject Specialists(SS) \\
3 & 15 &
\end{tabular}

They also produced new training modules, materials and new resources to contribute their efforts in capacity building. Most importantly, they conducted Training need analysis (TNA) and they identified the weaker areas, when needed; they provide customized trainings to enhance efficiencies. Through this CPDP, 994 trainings were conducted in FY 13-14, 949 trainings in FY 14-15 and they approached 23,880 teachers and heads in FY 1314, 19,500 teachers and heads in FY 14-15. One of the most effective things was that they standardized modules 
with the collaboration and guidance of Training Module standardization Committee (TMSC) at the Financial Management and Quality Assurance Test. CPDP utilizes three programs to train all of them. Continuous Teachers Development program (CTDP) was specific for teacher's training, School Leadership Development Program (SLDP) was specified for the trainings of the heads and Subject Based Support Program (SBSP) both caters to subject specialist work as facilitators, trainers, Mentors and teachers for the tasks assigned.Along with these programs CPDP utilizes the three trainings model too, their characteristics are as under in the table. With the help of these models, trainings become more effective and up to date. Trainers for these trainings were different
TOPs (training providing organizations) who having partnership with CPDP-PEF utilize different schools as training camps. Highly qualified trainers are being selected by this TPOs.Now there was a problem of selection of the TOPs. According to selection criteria, These TPOs were advised to submit their EOI, as per Punjab Procurement Regulatory Authority (PPRA) Rules, 2014. Through transparent selection, selected TPOs were asked to conduct Pilot trainings and after the valuation of those workshops, final recommendation for partnership was announced. And if any school teacher doesn't go for the trainings in that way the repute of the school would be affected. If training venues were $40 \mathrm{~km}$ apart from school then per day Rs. 1500 are paid to participants in trainings.

\begin{tabular}{|c|c|c|c|c|c|c|c|c|}
\hline \multirow[b]{2}{*}{ Sr. \# } & \multirow[b]{2}{*}{ Description } & \multicolumn{3}{|c|}{ Cluster-basedTraining } & \multicolumn{3}{|c|}{ PIVOT Training } & \multirow{2}{*}{$\begin{array}{l}\text { Camp Based } \\
\text { Training } \\
\begin{array}{l}\text { All of the } \\
\text { Teaching } \\
\text { staff }\end{array}\end{array}$} \\
\hline & & CTDP & \multicolumn{2}{|l|}{ SLDP } & $\begin{array}{l}\text { CTDP- } \\
\text { Subject } \\
\text { Based }\end{array}$ & \multicolumn{2}{|c|}{ SLDP-Need Based } & \\
\hline 1 & $\begin{array}{l}\text { No of training } \\
\text { days }\end{array}$ & 6 & \multicolumn{2}{|l|}{3} & 2 & \multicolumn{2}{|l|}{2} & 6 \\
\hline \multirow[b]{2}{*}{2} & Training time & \multirow{2}{*}{$\begin{array}{l}51 / 2 \\
\mathrm{hrs} / \text { day }\end{array}$} & \multirow{2}{*}{\multicolumn{2}{|c|}{$51 / 2 \mathrm{hrs} /$ day }} & & \multirow{2}{*}{\multicolumn{2}{|c|}{$8 \mathrm{hrs} /$ day }} & \multirow[b]{2}{*}{$6 \mathrm{Hrs} / \mathrm{day}$} \\
\hline & $\begin{array}{l}\text { (incl. 30min } \\
\text { Break) }\end{array}$ & & & & 8-hrs/day & & & \\
\hline 3 & $\begin{array}{l}\text { No of } \\
\text { participants in a } \\
\text { training }\end{array}$ & $30-35$ & \multicolumn{2}{|l|}{$15-20$} & $25-30$ & \multicolumn{2}{|c|}{$25-30$} & $\begin{array}{l}\text { Actual/all } \\
\text { staff } \\
\text { including } \\
\text { principals } \\
\text { and owner }\end{array}$ \\
\hline 4 & Target Audience & $\begin{array}{l}\text { Primary } \\
\text { Teachers }\end{array}$ & \multicolumn{2}{|c|}{ School Heads } & $\begin{array}{l}\text { Elementary } \\
\text { and } \\
\text { Secondary }\end{array}$ & \multicolumn{2}{|c|}{ School Heads/Teacher } & $\begin{array}{l}\text { Primary } \\
\text { Level }\end{array}$ \\
\hline 5 & $\begin{array}{l}\text { Training } \\
\text { Schedule }\end{array}$ & \multicolumn{7}{|c|}{ As approved } \\
\hline 6 & Venue Selection & \multicolumn{2}{|c|}{$\begin{array}{l}\text { Maybe PEF partner } \\
\text { school (within } 15 \mathrm{~km} \text { ) }\end{array}$} & \multicolumn{3}{|c|}{ TPO's own venue (above 15 km) } & \multicolumn{2}{|c|}{ Distant Schools } \\
\hline
\end{tabular}

\section{EDUCATION VOUCHER SCHEME (EVS)}

This strategy was introduced in 2006 to educate the children of underprivileged and less affluent areas who ignored due to social and financial constraints. To utilize the strong mechanism of education and to become able to get rid of the vicious circle of poverty and deprivation for next generation this program launched. Nine years, 14 phases, 36 districts, 3 lakh children, more than 1365 EVS partner schools, is the short story of this strategy. The age of beneficiaries, under EVS, are age group of 6 to 16 years.

In this program, schools selectedby single ownership, school rooms for primary must not less than 5 and for middle 8 and matric shouldn't be less than ten rooms. With few more things,the final selection basedon the physical verification. Under this program, in primary Rs. 450, in the middle, Rs. 500 and in metric Rs. 600 per student offered to partner schools.

\section{NEW SCHOOL PROGRAM (NSP)}

This strategy comes in 2008 as a pilot project at initial stages. This engages private entrepreneurs in the shape of schools of distant, remote and under-served areas of the province. It targeted areas where govt. schools are scarce NSP now adhere 1478 schools in 36 districts. 


\section{Region wise NSP Schools}

1400

1200

1000

800

600

400

200

0

\begin{tabular}{|c|c|c|c|c|c|}
\hline 14 & 170 & 11 & & 11 & 129 \\
\hline Districts & Schools & Districts & Schools & Districts & Schools \\
\hline \multicolumn{2}{|c|}{ Center } & \multicolumn{2}{|c|}{ South } & \multicolumn{2}{|c|}{ North } \\
\hline
\end{tabular}

New schools are opened in those areas where condition of at least 300 people in population is fulfilled and where within $1 \mathrm{~km}$ radius no other school exists. Women education is preferred too, enhancement is encouraged. Grace period of 50 enrolments was given to partners as well as to have Student-teacher ratio 30 to 1,1 toilet, 2 rooms and 2 teachers and water provision. New project with seven NGOs, to open new schools in allotted districts which were supposed to be verified by PEF.

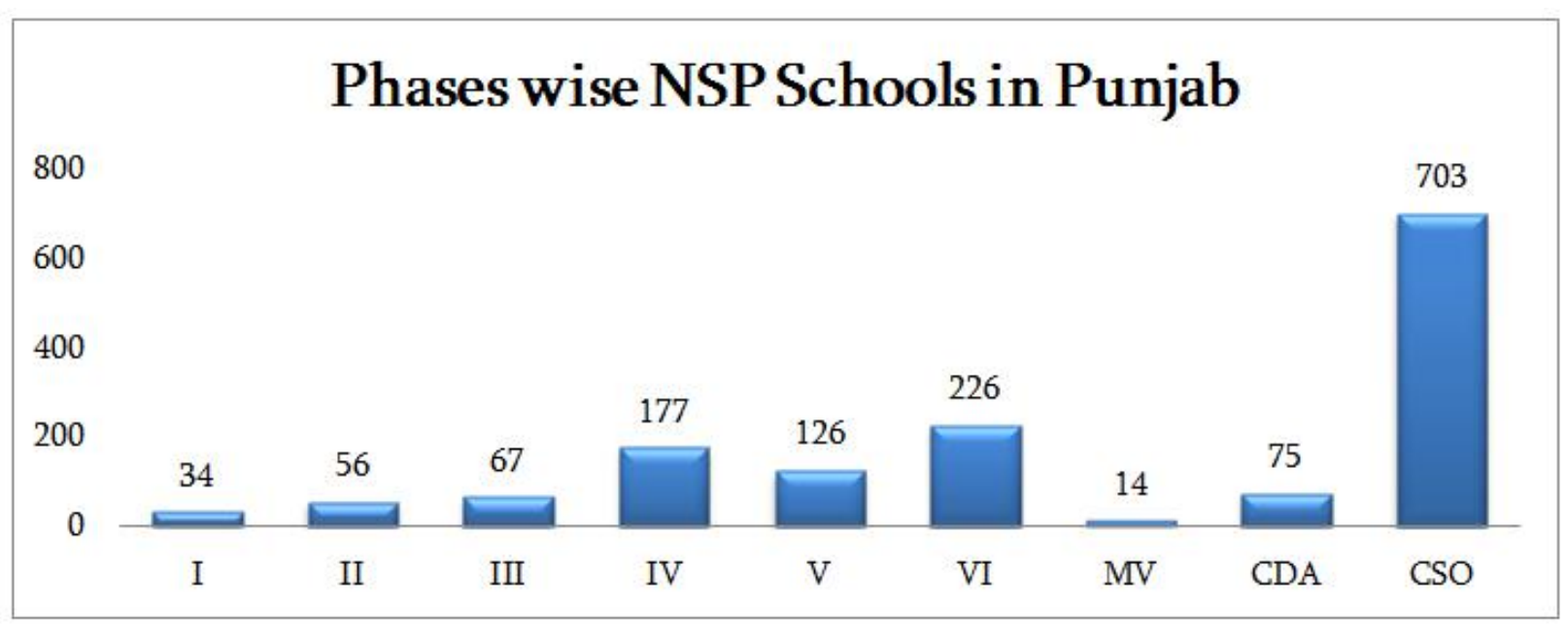

NSP emphasizes at retention of children too. It provides the partners, minimum standards in stipulated time. QAT assesses the learning of the students. Internal and external monitoring and evaluation conducted. They target the specifically weaker areas. It provides orientation of whole process, as well as SIS provided to NSP. Financial Assistance is provided; continuity is dependent for the partnership at the performance as per QAT standards. After partnership, no consideration will be charged to students. In order to noncompliance penalties and even cancellation of agreement will considered to be charged At initial till 50 students financial assistance will be settled and approved as per BODs rate approved. Later when partnership being existed at primary level Rs. 550 is given at per child rate, at elementary level Rs. 600 given at per child and for secondary level Rs. 700 is given for arts and Rs. 800 given for science par students. 


\section{SHINING STARS OF PEF}

To evaluate the performance and role of the PEF in above mention context in the reference we are can see the success stories of the PEF which are hereunder.

\section{MisbahS haheen-Voice of Cholistan}

She belongs to the Cholistan in Bahawalpur and studying in a remote school. Her school was under Cholistan Development Authority (CDA) and after the expiry of the project school taken by PEF along with other schools. She comes as the real hero of PEF and CDA partnership. She heard of culmination in CDA, one day she stopped the vehicle of DCO Bahawalpur and asked about the future of girls' education instead of paucity of resources for them. After the PEF-CDA saga, all 75 schools were enjoying free education. National Dailies and BBC declared her as "Malala-e-Cholistan."

\section{Faryal Ali- A girl par excellence}

Faryal belongs to Bhakkar, a remote and backward area. She is the daughter of a vegetable seller who uses the cart for that, along with three siblings from different schools. She is the first initiator as a girl from her family, who comes to school. She topped Sargodha board in 2013 by securing 970/1050 marks. Proveda great deal of motivation and encouragement to other girls to go to school. UK's international development department (DFID) highlighted her as a symbolof success.

\section{Govt. Schools under PEF}

The low-income level played a strong role to let Pakistan underdeveloped nation ${ }^{[5]}$,andtill yet only private schools practiced for the partnership agreement of PEF, but while observing the difference between PEF oriented schools and pure government sector schools government announced to hand over the 274 schools from the pure government to semi-government sector. Now in future prospective and while keeping the limitation. We can see different things. ${ }^{[5]}$

1- Does PEF overcome the reason behind its initiative? If not what are the factors, could be considered important for it.

2- Privately owned institutes always perform better to keep moving forward in the direction of profit. Could itadhere to the same level of efficiency?

3- Govt. decision of privatization of public schools wouldn't affect the reputation of public school governance? If then how?

4- What can be the further strategies for the sustainability of PEF with effectiveness?

\section{REFERENCES}

[1] Educational-articles. (2012). historical-backgroundof-education-in-Pakistan. Retrieved from http://sekho.com.pk: http://sekho.com.pk/educational-articles/historicalbackground-of-education-in-pakistan/
[2] Foundation, P. E. (2016). index.aspx. Retrieved from http://pef.edu.pk.pefsis.edu.pk: http://pef.edu.pk.pefsis.edu.pk/index.aspx

[3] Mission\&Vision. (2016). About/about-pefmission.aspx. Retrieved from http://pef.edu.pk.pefsis.edu.pk: http://pef.edu.pk.pefsis.edu.pk/About/about-pefmission.aspx

[4] Private_schools. (2002). education/private_schools.asp. Retrieved from http://www.yespakistan.com: http://www.yespakistan.com/education/private_scho ols.asp

[5] Abbas, S. K., Hassan, H. A., Asif, J., \& Zainab, F. (2018). HOW INCOME LEVEL DISTRIBUTION RESPONDS TO POVERTY: EMPIRICAL EVIDENCE FROM PAKISTAN. Global Scientific Journals, 6(3), 131-142.

[6] Times, D. (16 december,2015). decision-taken-tohand-over-274-primary-schools-to-pef. Retrieved from http://www.dailytimes.com.pk: http://www.dailytimes.com.pk/islamabad/16-Dec2015/decision-taken-to-hand-over-274-primaryschools-to-pef 